\title{
Response of Nitrogen Application in Fruit Trees: A Review
}

\author{
Kamal Kumar Pande ${ }^{1^{*}}$ and Dinesh Chandra Dimri ${ }^{2}$ \\ ${ }^{1}$ Horticulture, Krishi Vigyan Kendra (ICAR-VPKAS), Kafligair- 263628, Bageshwar, \\ Uttarakhand, India \\ ${ }^{2}$ Horticulture, G.B. Pant University of Agriculture and Technology, Pantnagar- 263145, U.S. \\ Nagar, Uttarakhand, India \\ *Corresponding author
}

\begin{abstract}
A B S T R A C T
Keywords

Nitrogen application, Fruit trees, Neem, Plant metabolism

Article Info

Accepted: 05 April 2020 Available Online: 10 May 2020

Nitrogen plays a pivotal role in fruit tree performance. It is a major constituent of plant cell and plays an important part in the plant metabolism. Considering the marked effect of nitrogen, its application in fruit trees has been investigated by several researches in India as well as in world. Previously, the studies remained confined to fruit yield and tree growth. However, with the advancement of time, interaction of nitrogen with other nutrients, management practices and growth regulators on leaf and soil nutrient status, fruit quality including nutritive value, antioxidant activity and shelf life were investigated. The major source of nitrogen fertilization was simple urea in past, but now the slow release nitrogen fertilizers like, neem coated urea is also available. Effect of such slow release nitrogen fertilizers on fruit trees were also studied by some workers. These findings are being presented systematically in this article.
\end{abstract}

\section{Introduction}

Nitrogen is the most important essential element needed in large quantity by the plants. It is a key constituent of cell and pigment system in green plant and found in proteins, amino acids, nucleic acids, phytohormones, enzymes, vitamins and many other organic compounds. It is involved in major biochemical reactions. The nitrogen can affect vegetative and reproductive aspects and quality characteristics of fruit trees. Clime and Bradt (1969) and Cahnoon (1971) reported that the nitrogen is such an element that produces the most striking responses on growth and yield in peaches. Crisosto et al., (1997) also emphasized that the response of peach trees to nitrogen fertilization is dramatic. Moreover, nitrogen levels may also affect the shelf life of fruits by influencing the pectic enzyme activity. Hobson (1963) 
showed that an increase in soil nitrogen level resulted in higher pectic enzyme activity. Response of controlled release nitrogenous fertilizers for horticultural crops in general and fruit crops in particular is less studies. Mido and Ishikawa (2016) also documented that in Citrus unshiu, 20 per cent reduction in the quantity of nitrogen through controlled release $\mathrm{N}$ fertilizer with respect to general recommendation for normal fertilizer during a period of five years had no adverse effect on tree growth, yield and fruit quality.

Response of nitrogen application on various characteristics of fruit trees are being discussed vide supra;

\section{Plant growth characteristics}

Young fruit trees require a large quantity of nitrogen and respond very favorably to it. In older trees adequate nitrogen supply ensures dark green foliage, long terminal growth and increase in trunk circumference. In addition to aerial vegetative growth, response of nitrogen has also been realized for root growth. In low nitrogen, roots are longer and poorly branched, whereas in high nitrogen, roots are short and well branched (Chadha, 2011). Response of nitrogen fertilization in fruit trees regarding the promotion of shoot growth and increase in shoot: root ratio was documented by other workers also (Taylor and May, 1967; Ro and Park, 2000 and Poorter and Nagel, 2000).

Vegetative growth of trees is linearly related to nitrogen application (Klein et al., 1989). Influence of nitrogen fertilization on general increase in vegetative growth of peach trees was reported by Kanwar and Nijjar (1983). Higher length of shoots, thickness of shoots and number of leaves per shoot were reported with high level of nitrogen (180 g per tree) as compare to low nitrogen level (80 g per tree) for three pruning severities in peach cv. Mit-
Ghamr in Egypt by Hassan (1990). However, over fertilization of nitrogen caused excessive shoot growth in fruit trees that adversely affected fruit production (Weinbaum et al., 1992).

Dhillon et al., (1990) reported increased shoot growth in grapes with increasing nitrogen fertilization from 300 to $500 \mathrm{~g}$ per vine. Kumar and Dhander (1996) observed increase in trunk girth with higher levels of nitrogen fertilization in pomegranate. Dhillon et al., (1992) applied graded doses of nitrogen in grapevine cv. Perlette for two successive years. They observed more trunk diameter with all the nitrogen treatments over control. The maximum trunk diameter in both the years was found under highest nitrogen dose (125 g/vine) that was closely followed by $100 \mathrm{~g}$ per vine and $50 \mathrm{~g}$ per vine nitrogen application. Similarly, shoot growth and weight of annual pruning wood also increased with increase in nitrogen level during both the study years.

Almaliotis et al., (1997) found cultivar difference in peach for response of nitrogen under greenhouse condition. They worked with three peach cultivars (Springcrest, Redheaven and Suncrest) and found that Springcrest and Redheaven achieved higher plant height and shoot growth with increasing concentration of nitrogen from 0.1 to $2 \mathrm{mM}$ in nutrient solution, while Suncrest had increasing growth values only up to $1 \mathrm{mM}$ nitrogen concentration and then the plant height as well as the shoot growth reduced significantly.

Response of different doses of nitrogen fertilization was also realized for growth attributes of litchi cv. China (Rai et al., 2002). They found that $\mathrm{N}$ application significantly influenced plant height, trunk girth, tree spread and tree volume. The maximum plant height $(3.66 \mathrm{~m})$, east- west tree spread (5.51 
$\mathrm{m})$, tree volume was recorded with $2000 \mathrm{~g} \mathrm{~N}$ tree $^{-1}$, whereas the maximum tree volume $\left(59.52 \mathrm{~m}^{3}\right)$, north- south tree spread $(5.54 \mathrm{~m})$ and trunk girth $(57.30 \mathrm{~cm})$ was recorded under $500 \mathrm{~g} \mathrm{~N}^{\mathrm{N}}$ tree $^{-1}$. Minimum values for all these parameters were obtained under control i.e. no application of $\mathrm{N}$ fertilizers. Therefore, it was concluded that $\mathrm{N}$ fertilization had dose dependent response in litchi. Bussi et al., (2003) showed increased trunk circumference growth in apricot for five consecutive years with highest nitrogen fertilization regime (150 kg per ha). Cmelik et al., (2006) also found a positive relationship between nitrogen rates and vegetative growth in Fuji apples. However, Wrona (2006) documented that trunk cross sectional area (TCSA) of apple was not affected by nitrogen fertilization.

Tahir et al., (2007) studied different nitrogen fertigation regimes in apple and found maximum trunk cross sectional area $\left(3.9 \mathrm{~cm}^{2}\right)$ and shoot growth $(41.8 \mathrm{~cm})$ with excess $\mathrm{N}$ fertigation. Although, varying doses of nitrogen given through drip fertigation in three peach cultivars (Pratap, Prabhat and Early Grande) resulted in non significant increase for stem girth (Banyal et al., 2015). However, in the same study differences for shoot extension growth and tree spread $(\mathrm{N}-\mathrm{S}$ and $\mathrm{E}-\mathrm{W}$ ) were significant, with maximum mean of three peach cultivars for shoot extension growth $(172.5 \mathrm{~cm}), \mathrm{N}-\mathrm{S}$ tree spread $(3.09 \mathrm{~m})$ and $\mathrm{E}-\mathrm{W}$ tree $\operatorname{spread}(3.21 \mathrm{~m})$ observed under highest level of nitrogen fertigation (490 g $\mathrm{N}$ per tree) that were statistically at par to $326 \mathrm{~g} \mathrm{~N}$ per tree, while minimum values for these growth parameters were obtained under lowest level of nitrogen fertigation (163 $\mathrm{g} \mathrm{N}$ per tree).

Olmstead et al., (2015) while working on response of nitrogen in mature peach trees found that trees receiving 90, 179, or $269 \mathrm{~kg}$ $\mathrm{ha}^{-1}$ of $\mathrm{N}$ tended to produce more shoots or wood than those receiving low $\left(45 \mathrm{~kg} \mathrm{ha}^{-1}\right.$ of
$\mathrm{N}$ ) or no $\mathrm{N}$ annually. They also found that the trunk cross-sectional area (TCSA) tended to be larger with higher $\mathrm{N}$ rates (179 and $269 \mathrm{~kg}$ $\mathrm{ha}^{-1}$ ) than in lower $\mathrm{N}$ rates. Rufat et al., (2010) also found that $\mathrm{N}$ application led to an increase in vegetative growth in peach that was manifested as an increase in weight of pruning wood.

Gill and Gill (2016) applied three levels of nitrogen (460, 690 and $920 \mathrm{~g}$ nitrogen tree ${ }^{-1}$ ) along with four levels of potassium in pear cv. Patharnakh and found maximum increase in trunk girth $(2.25 \mathrm{~cm})$ as well as shoot length $(14.58 \mathrm{~cm})$ with $920 \mathrm{~g} \mathrm{~N}^{-1}$ tree $^{-1}$, while with $460 \mathrm{~g} \mathrm{~N}^{-1} \mathrm{e}^{-1}$, only $1.44 \mathrm{~cm}$ and $12.17 \mathrm{~cm}$ increase in trunk girth and shoot length, respectively were recorded. Non significant differences for these parameters were recorded at varying doses of potassium within the same nitrogen level.

Radivojevic et al., (2016) proved that response of Promalin (6-BA+ $\left.\mathrm{GA}_{4+7}\right)$ on growth characteristics of apple nursery is dependent to nitrogen application. They found significantly longer leader under Promalin treatments only when the nitrogen application levels were above $100 \mathrm{~kg} \mathrm{ha}^{-1}$. Moreover, Promalin treatments had no effect on number of lateral branches in the absence of nitrogen application. Thus, significance of nitrogen application in plant growth cannot be over ruled even during use of new generation plant growth regulators, like Promalin.

Instead of overall growth of peach tree, Jordan et al., (2009) emphasized the evaluation of nitrogen fertilization on controlling the tree architecture to modify the source sink ratio and reducing the pruning cost by eliminating the excessive growth of unproductive wood.

Ram et al., (1999) worked in guava with three sources of nitrogen viz., urea, urea 
supergranule and neem coated urea, each containing 46 percent nitrogen. Three levels of each fertilizer that is 200,400 and $600 \mathrm{~g}$ tree- ${ }^{1}$ were given in two equal split doses. They found maximum vegetative growth in terms of plant height, annual increase in growth and plant spread with neem coated urea for each level of fertilizer application. Pande and Dimri (2018) worked on peach with neem coated urea along with calcium chloride sprays. They reported minimum annual extension growth and weight of pruning wood with lowest level of nitrogen (375 g per tree) that increased with increase in nitrogen fertilization doses. However, above $375 \mathrm{~g}$ per tree $\mathrm{N}$ application, this increase in annual extension growth unnecessarily increased pruning wood and not desired practically. Sprays of calcium chloride could also affect the growth parameter within a particular nitrogen regime.

\section{Yield and yield attributes}

Bloom density, fruit set and fruit retention are the yield characteristics that ultimately decide the production and productivity of fruit trees. Influence of nitrogen on all these yield characteristics is indispensable (Chattopadhyay, 1994). Sharma (2006) proposed that plants with adequate nitrogen and good carbohydrate assimilation are found to make moderate vegetative growth and bear a satisfactory crop. He further suggested that plants with plenty of nitrogen available have low $\mathrm{C}$ : $\mathrm{N}$ ratio, which is not desirable for proper set in fruit plants.

Hassan (1990) tried to establish the relation between nitrogen nutrition and severity of pruning in peach. He found the maximum yield $\left(47.86 \mathrm{~kg} \mathrm{tree}^{-1}\right)$ from those peach trees that had 200 shoots and received $180 \mathrm{~g} \mathrm{~N}$ tree 1. However, it was statistically at par (44.59 $\mathrm{kg}$ tree $^{-1}$ ) to 200 shoot and $90 \mathrm{~g} \mathrm{~N}$ tree $^{-1}$. Although significantly lower yields were noticed for other treatments viz., 300 shoots +
$90 \mathrm{~g} \mathrm{~N}$ tree ${ }^{-1}, 300$ shoots $+180 \mathrm{~g} \mathrm{~N}$ tree ${ }^{-1}, 100$ shoots $+90 \mathrm{~g} \mathrm{~N}$ tree ${ }^{-1}$ and 100 shoots $+180 \mathrm{~g}$ $\mathrm{N}$ tree $^{-1}$. It was also elucidated that the increase in fruit weight had more pronounced effect on increasing yield than the number of fruits per tree. Thus balancing the vegetative and reproductive growth through pruning and nitrogen fertilization was ascribed.

Six treatments comprising five nitrogen doses viz., $25 \mathrm{~g}, 50 \mathrm{~g}, 75 \mathrm{~g}, 100 \mathrm{~g}$ and $125 \mathrm{~g}$ per tree and one control were assigned on grapevine for two consecutive years (Dhillon et al., 1992). The results showed that in first year there is a steady increase in number of bunches per vine, berry weight, bunch weight and fruit yield with increasing nitrogen levels and maximum values of all these parameters (46 bunches per vine, $1.77 \mathrm{~g}$ berry weight, $395.3 \mathrm{~g}$ bunch weight and $18.6 \mathrm{~kg}$ yield per vine) were found under the highest level of nitrogen (125 g per vine). However, in second year of study, maximum number of bunches per vine (60 bunches per vine), maximum berry weight $(1.83 \mathrm{~g})$, maximum bunch weight $(430.5 \mathrm{~g})$ and maximum yield $(25.8 \mathrm{~kg}$ per vine) were obtained under $100 \mathrm{~g}$ nitrogen per vine.

Daane et al., (1995) applied four nitrogen fertilization treatments (100, 175, 250 and $325 \mathrm{lb}$ N/acre) along with control (no nitrogen) in nectarine and found that total yield was not affected by the nitrogen levels above $100 \mathrm{lb} / \mathrm{acre}$, but the time of fruit maturity was delayed by 4 to 5 days. Saenz et al., (1997) obtained significantly higher fruit weight and fruit yield in peach with nitrogen fertilization than unfertilized control. They also proved that the increased fruit yield with nitrogen fertilization is due to the extended fruit development period that leads to increase in amount of assimilate accumulation.

Singh and Chauhan (2002) examined different levels of nitrogen for peach at Rajgarh in Himanchal Pradesh. They found that fruit 
yield was increased with increasing levels of nitrogen fertilization upto $500 \mathrm{~g}$ per tree and thereafter the yield was decreased but the differences were not significant. The highest yield with $500 \mathrm{~g} \mathrm{~N}$ per tree $\left(55.95 \mathrm{~kg}_{\text {tree }}{ }^{-1}\right.$ ) was attributed to heavier fruits and increased fruit set than other levels of nitrogen. The lowest yield of peach was obtained with $300 \mathrm{~g}$ $\mathrm{N}$ per tree $\left(48.03 \mathrm{~kg}\right.$ tree $\left.^{-1}\right)$. Sharma and Chauhan (2004), while working on full bearing peach cv. July Elberta in Himanchal Pradesh also found significantly higher yield $\left(45.9 \mathrm{~kg} \mathrm{tree}^{-1}\right)$ in preach plants with $500 \mathrm{~g} \mathrm{~N}$ per tree as compared to $250 \mathrm{~g} \mathrm{~N}$ per tree (37.3 $\left.\mathrm{kg} \mathrm{tree}^{-1}\right)$ and $750 \mathrm{~g} \mathrm{~N}$ per tree $\left(42.2 \mathrm{~kg}\right.$ tree $\left.^{-1}\right)$ at same level of potassium (600 g per tree). However, yield as well as fruit weight were not found to differ significantly under different nitrogen fertilization regimes in litchi (Rai et al., 2002) and in apple (Wargo et al., 2003; Wrona, 2006).

Rakiceevic et al., (2007) applied different rates of NPK fertilizer of formula 8:16:24 in plum and found maximum yield with $400 \mathrm{~kg}$ per ha fertilizer. Increase in fertilizer doses above it resulted in reduction in fruit yield. Tahir et al., (2007) also observed maximum fruit yield $(22,500 \mathrm{~kg}$ per ha) with moderate $\mathrm{N}$ fertigation in apple and the yield reduced significantly for low $(19,900 \mathrm{~kg}$ per ha) as well as excess $\mathrm{N}$ fertigation $(18,300 \mathrm{~kg}$ per ha). Singh et al., (2009) applied various levels of NPK in apple cv. Red Delicious and found early fruit maturity under lower doses (300: 150: 450), however maximum fruit yield was recorded with higher doses of NPK (600: 300: 900). Dhillon et al., (2011) proposed that at higher doses of nitrogen, availability and uptake of nutrients increased that led to the better yield attributes in pomegranate cv. Kandhari. However, Rufat et al., (2010) indicated that the yield components in peach were not affected with nitrogen fertilization under deficit irrigation regime. Domingo et al., (2012) reported a positive yield effect for nitrogen applied to fully irrigated peaches trees, while the opposite was observed when the irrigation restriction was applied during stage III of fruit growth. Therefore, the response of nitrogen may vary and dependent on water availability and consequently on soil type.

Banyal et al., (2015) applied various levels of nitrogen through drip irrigation in three peach cultivars viz., Partap, Prabhat and Early Grande. The study revealed the significant differences for fruit weight and yield. Maximum mean fruit weight $(61.92 \mathrm{~g})$ and highest fruit yield $\left(26.84 \mathrm{~kg} \mathrm{tree}{ }^{-1}\right)$ were obtained under highest level of nitrogen fertigation (490 $\mathrm{g}$ per tree) that were statistically at par to $326 \mathrm{~g} \mathrm{~N}$ per tree, while minimum mean fruit weight $(50.96 \mathrm{~g})$ and fruit yield $\left(21.37 \mathrm{~kg}\right.$ tree $\left.^{-1}\right)$ were found under lowest level of nitrogen fertrigation (163 g N per tree). Medium levels of both nitrogen (690 $\mathrm{g} \mathrm{tree}^{-1}$ ) and potassium (900 $\mathrm{g} \mathrm{tree}^{-1}$ ) gave higher fruit set (23.28 per cent) and yield $\left(94.5 \mathrm{~kg}\right.$ tree $\left.^{-1}\right)$ in pear cv. Patharnakh as compared to low and higher levels (Gill and Gill, 2016).

Olmstead et al., (2015) examined the bud distribution pattern in peach as influenced by different levels of nitrogen fertilization. They found that the trees receiving the highest level of nitrogen (269 $\mathrm{kg} \mathrm{ha}^{-1}$ ) had more vegetative as well as floral buds than those with low nitrogen (45 $\left.\mathrm{kg} \mathrm{ha}{ }^{-1}\right)$ fertilization. In consideration with these results, they predicted that the lowest nitrogen treatment that decreased vegetative and floral buds may lead to smaller trees with reduced yield in subsequent years, while trees with highest level of nitrogen will produce larger canopies, requiring heavy pruning to maintain the optimum productivity.

The effect of controlled release nitrogenous fertilizers on fruit tree performance is less 
studied. However, Ram et al., (1999) reported significant increase in number of fruits and yield in guava cv. Sardar with slow releasing nitrogen fertilizer (neem coated urea) over same dose of normal urea. Pande and Dimri (2018) reported in peach that $375 \mathrm{~g}$ nitrogen per tree through neem coated urea along with three applications of $1.0 \%$ calcium chloride sprays were most suitable for optimum yield in peach cv. Red June. Because, increase in nitrogen doses above this level imparted redundant vegetative growth that did not contributed significantly in yield and eventually removed during winter pruning. Calcium chloride sprays were effective within a nitrogen regime in reducing the fruit drop and consequently increased fruit retention and yield.

\section{Quality and shelf life}

Sugar and acidity are the main quality characteristics for edible quality of peach after fruit firmness (Moreau- Rio et al., 1995). Moreover, sugar taste is affected by acid content, e.g., sucrose perception is concealed by citrate (Shifferstein and Fritjers, 1990; Bonnans and Noble, 1993) and that of fructose by malate (Pangborn, 1963). However, fruit quality attributes are not only limited to sugar, acidity or firmness but fruit size, shape and appearance also exerts consumer's preference. In addition to these above mentioned parameters, bioactive compounds i.e., antioxidants are also gaining importance as quality attributes for fruits because of their health benefits as their consumption leads to the lower incidence of cardiovascular and neoplastic diseases (Ferretti et al., 2010 and Ferretti et al., 2014). Several workers observed the effects of nitrogen fertilization on different quality characteristics of fruits which are being presented underneath.

Hassan (1990) in his experiment on severity of pruning and nitrogen nutrition in peach revealed that the total soluble solid (TSS) content of fruits was maximum $\left(13.62{ }^{0}\right.$ Brix $)$ under most severe pruning (100 shoots) and $180 \mathrm{~g} \mathrm{~N}$ tree $^{-1}$. Although, it was statistically at par to 100 shoots $+90 \mathrm{~g} \mathrm{~N}$ tree $^{-1}\left(13.57^{0}\right.$ Brix $)$ and 200 shoot $+180 \mathrm{~g} \mathrm{~N}^{-1} \mathrm{te}^{-1}\left(13.42^{0}\right.$ Brix $)$. Minimum TSS (11.95 ${ }^{0}$ Brix) was recorded with 300 shoots $+90 \mathrm{~g} \mathrm{~N}$ tree ${ }^{-1}$. He also found that under same level of pruning severity, significant differences for TSS due to different doses of nitrogen fertilization were noticed only at medium pruning severity i.e. 200 shoots. He further stated that the results regarding acidity and TSS/Acid ratio were non significant for all the treatments.

Dhillon et al., (1992) conducted a two year study on response of nitrogen fertilization levels on grapevine and observed some of the quality parameters. In first year, the highest TSS content (14.8\%) of berries was found under lowest nitrogen dose (25 g per vine) followed by no nitrogen application, while minimum TSS content (13.3\%) was recorded under highest nitrogen dose of $125 \mathrm{~g} \mathrm{~N}$ per vine. In second year also, the minimum TSS content (13.0\%) was measured under $125 \mathrm{~g} \mathrm{~N}$ per vine but highest TSS content $(15.3 \%)$ was recorded under $50 \mathrm{~g} \mathrm{~N}$ per vine. The lowest berry acidity was recorded under $25 \mathrm{~g} \mathrm{~N}$ per vine and $50 \mathrm{~g} \mathrm{~N}$ per vine in first and second year, respectively. Highest berry acidity was measured under $125 \mathrm{~g} \mathrm{~N}$ per vine in both the years. $125 \mathrm{~g} \mathrm{~N}$ per vine also resulted in minimum TSS: acid ratio, while maximum was found under $25 \mathrm{~g} \mathrm{~N}$ per vine and $50 \mathrm{~g} \mathrm{~N}$ per vine in first and second year of the study, respectively.

Marcelle (1995) cited in his research article on mineral nutrition and fruit quality that very often a negative correlation exists between nitrogen content and fruit firmness. He further postulated that the best storage quality of fruits is associated with a low N/Ca ratio. Hernandez- Fuentes et al., (2002) also found that application of soil and foliar fertilizers 
having lower nitrogen content resulted in increased pulp firmness in peach fruits, while fertilizer application with higher nitrogen content reduced the fruit firmness.

Singh and Chauhan (2002) found that varying levels of nitrogen application has marked effect on fruit weight as well as on fruit size and consequently on grading of fruits in peach cv. July Elberta. The maximum fruit weight, highest percentage of three layer fruits $(5.6 \mathrm{x}$ $5.4 \mathrm{~cm}$ and above size) and minimum percentage of loose grade fruits $(4.9 \times 4.7 \mathrm{~cm}$ size) were produced by $500 \mathrm{~g}$ nitrogen per tree. The maximum fruit weight $(96.28 \mathrm{~g})$ under $500 \mathrm{~g} \mathrm{~N}^{-1} \mathrm{tre}^{-1}$ was significantly higher than both higher (600 and $700 \mathrm{~g} \mathrm{~N}$ tree $^{-1}$ ) as well as lower (300 and $400 \mathrm{~g} \mathrm{~N}$ tree $^{-1}$ ) level of nitrogen fertilization. They also reported significant influence of nitrogen levels on total soluble solids (TSS) of fruit with maximum values (15.58) under $600 \mathrm{~g} \mathrm{~N}$ tree $^{-1}$. But different nitrogen levels could not affect the fruit acidity significantly. Rai et al., (2002) also found non significant differences for fruit acidity in litchi under much larger range of nitrogen fertilization comprising nine treatments viz., 0, 250, 500, 750, 1000, 1250, 1500, 1750 and $2000 \mathrm{~g} \mathrm{~N}$ tree ${ }^{-1}$. However, application of $500 \mathrm{~g} \mathrm{~N}$ tree $^{-1}$ was found the best with respect to fruit length, fruit breadth, fruit volume and TSS.

Sharma and Chauhan (2004) also observed significantly higher total soluble solids and total sugars in peach with application of $500 \mathrm{~g}$ nitrogen per tree than application of $250 \mathrm{~g}$ and $750 \mathrm{~g}$ nitrogen per tree. The effect of nitrogen levels was non significant for fruit acidity. They suggested that the increase in total soluble solids and sugars with nitrogen application may probably be due to more synthesis of carbohydrates and other metabolites followed by their translocation to storage organs. However, no effect of nitrogen application on soluble solids concentration was noticed in peach by Domingo et al., (2012). Cmelik et al., (2006) also reported no significant influence of different nitrogen doses on external and internal fruit quality in Fuji apples.

Jia et al., (2006) applied three levels of complete liquid fertilizers containing $60 \mathrm{ppm}$ (medium), $120 \mathrm{ppm}$ (high) and $240 \mathrm{ppm}$ (super high) nitrogen in peach and found that average fruit weight was increased as the fertilizer application level was increased from medium to super high. But the TSS content of juice was the lowest $\left(13.5^{0}\right.$ Brix $)$ under the super high treatment $(240 \mathrm{ppm} N)$. Statistically at par differences were noticed for titratable acidity under high and super high treatments, however these were significantly lower than under medium nitrogen treatment. He also reported that flesh firmness differed significantly among the three treatments at harvest and found highest under medium treatment (120 ppm N), while the lowest fruit firmness was observed under super high treatment (240 ppm N). Another important finding of this experiment was that the high levels of nitrogen fertilizer application impairs an early degradation of flesh polyuronides resulting in the accumulation of low molecular weight water soluble polyuronides (WSP). This may ultimately cause the inferior flesh texture of over fertilized peach fruit.

Tahir et al., (2007) found significantly lower fruit calcium content and higher postharvest loss during storage with excess nitrogen fertigation in apple. Highest fruit firmness and maximum TSS in apple cv. Red Delicious was recorded with 300: 300: 900 and 600: 300: 900 NPK fertilization, respectively (Singh et al., 2009). However, Domingo et al., (2012) found the positive effect of nitrogen application on peach fruit firmness, especially for high level $\left(120 \mathrm{~kg} \mathrm{~N} \mathrm{ha}^{-1}\right)$ and suggested that the delayed fruit maturation is 
the reason for this phenomenon. Nevertheless, Souza et al., (2013) reported increased fresh mass and reduced flesh firmness and titratable acidity with increasing nitrogen fertilization levels in Fuji apples. They also observed more evident effect of nitrogen doses on fruit firmness during storage than at harvest.

Falguera et al., (2012) in their work with peach cv. Andross evaluated three nitrogen fertigation treatments consisting of $0 \mathrm{~kg} \mathrm{~N}$ ha ${ }^{1}, 60 \mathrm{~kg} \mathrm{~N} \mathrm{ha}^{-1}$ and $120 \mathrm{~kg} \mathrm{~N} \mathrm{ha}^{-1}$ and reported that fruits from trees receiving nitrogen supplementation may reach their commercial maturity later and at that time their polyphenol oxidase activity was higher that may lead to subsequent problem in postharvest handling. However, non significant differences were found between the application of $60 \mathrm{~kg} \mathrm{~N} \mathrm{ha}^{-1}$ and $120 \mathrm{~kg} \mathrm{~N}$ $\mathrm{ha}^{-1}$.

Varying levels of nitrogen fertigation in three peach cultivars (Partap, Prabhat and Early Grande) could not impart significant differences for fruit TSS content (Banyal et $a l ., 2015)$. Nevertheless, they were able to alter fruit length and fruit diameter, significantly. Maximum mean fruit length $(47.58 \mathrm{~mm})$ and fruit diameter $(50.30 \mathrm{~mm})$ were obtained under highest level of nitrogen fertigation (490 $\mathrm{g} \mathrm{tree}^{-1}$ ) that were statistically at par to $326 \mathrm{~g} \mathrm{~N}$ per tree with $46.30 \mathrm{~mm}$ and $47.32 \mathrm{~mm}$ mean fruit length and diameter, respectively. Whereas, minimum mean fruit length $(43.86 \mathrm{~mm})$ and diameter $(42.66 \mathrm{~mm})$ were measured under lowest level of nitrogen fertrigation (163 $\mathrm{g} \mathrm{N}$ per tree).

Saini et al., (2013) in their two year study, applied three nitrogen levels (400, 500 and $600 \mathrm{~g} \mathrm{~N}$ per tree) through urea in plum and reported significant differences for various physico- chemical fruit quality attributes. During both of the years, maximum fruit length $(38.57 \mathrm{~mm}$ and $39.00 \mathrm{~mm})$, diameter
(39.14 $\mathrm{mm}$ and $40.15 \mathrm{~mm}$ ) and fruit weight $(38.00 \mathrm{~mm}$ and $38.10 \mathrm{~mm})$ were observed with medium doses of nitrogen fertilization i.e., $500 \mathrm{~g} \mathrm{~N}$ per tree. However, maximum total sugars as well as reducing sugars were recorded with $600 \mathrm{~g} \mathrm{~N}$ per tree followed by 500 and $400 \mathrm{~g} \mathrm{~N}$ per tree.

Although work on effect of neem coated urea on fruit quality is very scanty, Ram et al., (1999) showed in their study with guava that neem coated urea fertilization was resulted in significantly higher TSS and reducing sugar content as compared to same dose of normal urea. However, non- significant observations with respect to acidity were noticed. Better quality attributes with neem coated urea might be due to reduced leaching and nitrification losses and continuous rather than a fluctuating supply of nitrogen (Alila and Srivastava, 2008). Better chemical attributes of peach fruits in terms of TSS- Acid ratio and ascorbic acid content were reported with $375 \mathrm{~g}$ per tree $\mathrm{N}$ application through neem coated urea and these were most pronounced with sprays of calcium chloride @ 1.0\% (Pande and Dimri, 2018)

Mineral nutrition in general and nitrogen fertilization especially has been found to influence the antioxidant composition of fruits and vegetables (Dumas et al., 2003; Kalt, 2005; Bernard et al., 2009 and Maggio et al., 2013). Lopez et al., 2014) showed the strong influence of nitrogen fertilization on antioxidant activity of lettuce measured by the ABTS [2, 2'- azino-bis (3- ethylbenzothiazoline-6- sulphonic acid] method. The lowest antioxidant activity was observed in those lettuce plants that received no nitrogen ferti-irrigation. However, the increased antioxidant activity with nitrogen application was not found to depend on the origin source of nitrogen i.e., organic manure or chemical fertilizer. Hakkinen and Torronen (2000) in strawberries, Lombardi- Boccia et al., (2004) 
in plums, Valavanidis et al., (2009) in apples, Toselli et al., (2010) in nectarines and Yuri et al., (2012) in apples, also found that the organically produced fruits do not contain higher levels of antioxidants than chemically fertilized fruits. In other words origin of nutrient or nitrogen did not influence the antioxidant content but the availability and levels of nitrogen do matter.

Several other workers have reported higher antioxidant content in organically grown fruits than fertilizer cultivation techniques (Carbonaro and Mattera, 2001; Jin et al., 2011; Crecente-Campo et al., 2012; Tarozzi et al., 2006 and Wang et al., 2008). OchoaVelasco et al., (2016) while working with greenhouse cultivated tomato, found that antioxidant activity of tomato fruits as measured by DPPH (2,2- diphenyl-1picrylhidrazyl radical) and FRAP (Ferric reducing antioxidant power) methods showed an increase with the reduction of nitrogen dose. However, Unuk et al., (2006) reported no consistent and significant effect of various nitrogen fertilization regimes on fruit polyphenol content in apple. Pande et al., (2017) observed that different nitrogen fertilization levels through neem coated urea had significant effect on antioxidant activities of peach fruits; however under same nitrogen regime, calcium chloride sprays could not affect the antioxidant activities of peach fruits significantly.

Therefore, the researchers are not unanimous for the influence of nutrient management on antioxidant capacity of fruits and their findings are rather contradictory.

\section{Leaf nutrient status}

Application of higher nitrogen level through soil significantly increased nitrogen content in peach leaves (Hassan, 1990). Almaliotis et al., (1997) reported that increasing levels of nitrogen led to increase the leaf nitrogen content and also influenced the status of other nutrients in peach leaves. This influence had significantly positive correlation for $\mathrm{K}$ but significantly negative for $\mathrm{P}, \mathrm{Ca}, \mathrm{Mg}$ and $\mathrm{Mn}$. Singh and Singh (2002) also concluded that application of nitrogen appeared to have increased the effectiveness of the peach tree in absorbing and utilizing available $\mathrm{K}$ and Mn. Olmstead et al., (2015) applied five treatments of nitrogen fertilization in peach viz., $0 \mathrm{~kg} \mathrm{Nha}^{-1}, 45 \mathrm{~kg} \mathrm{Nha}^{-1}, 90 \mathrm{~kg} \mathrm{Nha}^{-1}, 179$ $\mathrm{kg} \mathrm{Nha}^{-1}$ and $269 \mathrm{~kg} \mathrm{~N} \mathrm{ha}^{-1}$. They found lower leaf $\mathrm{N}$ concentration in the 0 and $45 \mathrm{~kg} \mathrm{~N}^{-1}$ than the highest two $\mathrm{N}$ treatments.

Fallahi et al., (1993) reported that higher nitrogen application in sweet cherry cv. Bing resulted in higher concentration of leaf nitrogen but lower phosphorus, potassium and calcium. They applied various doses of nitrogen in peach cv. July Elberta and found significantly increasing trend for leaf nitrogen content and decreasing for leaf phosphorus, potassium and calcium with incremental levels of nitrogen fertilization.

Highest leaf nitrogen content $(3.07 \%)$ and lowest leaf phosphorus $(0.205 \%)$, potassium $(2.25 \%)$ and calcium $(2.49 \%)$ was recorded under $700 \mathrm{~g} \mathrm{~N}$ per tree, while lowest leaf nitrogen $(2.87 \%)$ and highest leaf phosphorus $(0.218 \%)$, potassium $(2.56 \%)$ and calcium $(2.89 \%)$ was obtained under $300 \mathrm{~g} \mathrm{~N}$ per tree. Similarly, Arora et al., (1999) observed significantly higher nitrogen and lower phosphorus and potassium content in peach leaves with increasing levels of nitrogen fertilization. However, Wrona (2006) reported non significant increase in leaf nitrogen content with increasing levels of nitrogen fertilization from 0 to $100 \mathrm{~kg}$ per ha in apple.

Decrease in leaf phosphorus and potassium content was noticed with increasing levels of nitrogen fertilization from 300 to $600 \mathrm{~g} \mathrm{~N}$ per 
tree in apple cv. Red Delicious (Singh et al., 2009). Gill and Gill (2016) made a study on fertilizer management in pear and observed that increase in nitrogen level from $460 \mathrm{~g} \mathrm{~N}$ tree $^{-1}$ to $690 \mathrm{~g} \mathrm{~N}$ tree ${ }^{-1}$ to $920 \mathrm{~g} \mathrm{~N}$ tree $^{-1}$ resulted in consistent increase in leaf $\mathrm{N}$ content. It was $1.85 \%$ under $460 \mathrm{~g} \mathrm{~N}^{-1} \mathrm{tree}^{-1}$, $1.97 \%$ under $690 \mathrm{~g} \mathrm{~N}^{-1}$ tree ${ }^{-1}$ and $2.14 \%$ under $920 \mathrm{~g} \mathrm{~N}^{\mathrm{N}} \mathrm{tree}^{-1}$. They also find out that varying levels of $\mathrm{N}$ fertilization influenced the content of other nutrients in leaves considerably. Increase in the rate of $\mathrm{N}$ fertilization also increased leaf $\mathrm{K}$ content from $0.91 \%$ under $460 \mathrm{~g} \mathrm{~N}^{-1}$ tree $1.15 \%$ under $690 \mathrm{~g} \mathrm{~N}^{-1}$ tree $^{-1}$ to $1.17 \%$ under $920 \mathrm{~g} \mathrm{~N}$ tree ${ }^{-1}$. But the increase in leaf $\mathrm{P}$ content was experienced only up to $690 \mathrm{~g} \mathrm{~N}$ tree ${ }^{-1}$.

Leaf $\mathrm{Ca}$ and $\mathrm{Mg}$ content showed inverse relationship with increasing levels of $\mathrm{N}$ fertilization. Maximum leaf $\mathrm{Ca}(2.00 \%)$ and $\mathrm{Mg}(0.63 \%)$ content were found under $460 \mathrm{~g}$ $\mathrm{N}$ tree ${ }^{-1}$, while they decreased with increasing levels of $\mathrm{N}$ fertilization and minimum values of leaf $\mathrm{Ca}(1.79 \%)$ and $\mathrm{Mg}(0.50 \%)$ were observed under $920 \mathrm{~g} \mathrm{~N}$ tree $^{-1}$.

Ram et al., (1999) proved the better efficacy of neem coated urea over normal urea by depicting the higher leaf $\mathrm{N}$ content under same dose of neem coated urea. They took three doses (200 g, $400 \mathrm{~g}$ and $600 \mathrm{~g}$ ) of both normal and neem coated urea. The minimum leaf $\mathrm{N}$ content $(1.54 \%)$ was recorded under 200 g normal urea, while it was $1.84 \%$ for same dose $(200 \mathrm{~g})$ of neem coated urea. Likewise, the maximum leaf $\mathrm{N}$ content $(2.10 \%)$ was found under neem coated urea, while it was only $1.61 \%$ under same dose (600 g) of normal urea. Pande et al., (2018) recorded that increase in nitrogen fertilization levels through neem coated urea led to increase leaf nitrogen content and decrease leaf phosphorus, potassium and calcium content in peach.

\section{Soil nutrient status}

The literature pertaining to the short term effect of different nitrogen regimes on soil nutrient status is very meager. Nevertheless, the available information on this aspect documented by some workers is being presented in the coming text. Squires (2013) conducted a study entitled "The impact of different nitrogen fertilizer rates on soil characteristics, plant properties and economic returns in a southeastern Minnesota cornfield". He found that soil nitrate concentrations generally increased with greater nitrogen inputs, however soil phosphates were very variable within treatments and did not follow any trend. Garhwal et al., (2014) in their study with Kinnow mandarin reported that soil nitrogen content increased significantly with continuous increase in nitrogen doses. However, soil phosphorus and potassium were not affected significantly by different nitrogen regimes. Response of nutrient status of rice soil to nitrogen fertilization was studied by Saha et al., (2015). They found parallel trend for soil nitrogen availability with nitrogen fertilization levels, however, the application of different nitrogen levels did not result in significant variation for available soil phosphorus and potassium status. In grapevine the nitrate concentration in the soil increased with increasing nitrogen rates but differences for other nutrients were less evident (Silva et al., 2016). Pande et al., (2018) reported that varying levels of nitrogen fertilization through neem coated urea significantly affected the available nitrogen in soil, differences in other soil nutrients were not manifested.

In conclusion, nitrogen application is capable to influence various characteristics of fruit trees significantly. Its effects are not only limited to growth and yield but considerably affect quality parameters, antioxidant activity 
and shelf life of fruits. Mostly the effects are dose dependent and need to be standardized precisely as per the production system. With changing scenario of orcharding i.e. high density planting, short tree stature, drip fertigation and use of slow release nitrogen fertilizers and consumer's preference for quality fruits, there is need to review the past findings and refine for new ones. This discussion will be useful in this endeavor by widening the understanding for responses of nitrogen application in fruit trees.

\section{Acknowledgement}

This is the part of Ph.D. Thesis research (GBPUAT, Pantnagar) of the first author. The required facilities provided by GBPUAT, Pantnagar and sponsoring by the Director, ICAR-VPKAS, Almora are duly acknowledged.

\section{References}

Alila, P. and Srivastava, A.K. 2008. Slow release fertilizers and citrus: Emerging facts. Agric. Rev., 29 (2): 99-107.

Almaliotis, D., Therios, I. and Karatassiou, M. 1997. Effect of nitrogen fertilization on growth, leaf nutrient concentration and photosynthesis in three peach cultivars. Acta Hort., 449 (2): 529- 534.

Arora, R.L., Tripathi, S. and Singh, R. 1999. Effect of nitrogen on leaf mineral nutrient status, growth and fruiting in peach. Indian J. Hort., 56 (4): 1-4.

Banyal, S.K., Sharma, D. and Jarial, K. 2015. Effect of nitrogen fertigation on yield and fruit quality of low chilling peaches under subtropical conditions of Himanchal Pradesh. Indian J. Hort., 72 (4): 457-460.

Benard, C., Gautier, H., Bourgaud, F., Grasselly, D., Navez, B., Caris- Veyrat, C., Weiss, W. and Genard, M. 2009. Effects of low nitrogen supply on tomato (Solanum lycopersicum) fruit yield and quality with special emphasis on sugars, acids, ascorbate, caroenoids and phenolic compounds. J. Agric. Food Chem., 57: 4112- 4123.

Bonnans, S. and Noble, A.C. 1993. Effect of sweetener type and of sweetener and acid levels on temporal perception of sweetness, sourness and fruitiness. Chemical senses, 18 (3): 273-283.

Bussi, C., Besset, J. and Girard, T. 2003. Effects of fertilizer rates and dates of application on apricot (cv. Bergeron) cropping and pitburn. Scientia Horticulturae, 98: 139147.

Cahnoon, G.A. 1971. Effect of N,P and K on yield and quality of peaches. Hort. Abst. 43 (12).

Carbonaro, M. and Mattera, M. 2001. Poltphenoloxidase activity and polyphenol levels in organically and conventional grown peach (Prunus persica L., cv. Regina bianca) and pear (Pyrus communis L., cv. Williams). Food Chem., 72 (4) 419- 424.

Chadha, T.R. 2011. Textbook of Temperate Fruits. Indian Council of Agricultural Research, New Delhi.

Chattopadhyay, T.K. 1994. Nutrition of fruit plants and orchard manuring practices. In:

A. Textbook on Pomology. Chattopadhyay, T.K. (ed.) Kalyani Publishers, New Delhi. 144- 185.

Clime, R.A. and Bradt, O.A. 1969. Effect of several fertilizers and cultural treatments on growth, yield and leaf nutrient composition of peaches. Hort. Abst. 41 (5).

Cmelik, Z., Tojnko, S. and Unuk, T. 2006. Fruit quality of fuji apples as affected by crop load and rates of nitrogen. Acta Hort., 721: 147- 152.

Crecente- Campo, J., Nunes- Damaceno, M., Romero- Rodriguez, M.A. and VazquezOderiz, M.L. 2012. Color, anthocyanin pigment, ascorbic acid and total phenolic compound determination in organic versus conventional strawberries (Fragaria $\mathrm{x}$ ananassa Duch, cv. Selva). $J$. Food Compos Anal., 28 (1): 23-30.

Crisosto, C.H., Johnson, T., Dejong and Day, 
K.R. 1997. Orchards factors affecting post harvest stone fruit quality. Hort. Sci., 32: 820-823.

Daane, K.M., Johnson, R.S., Michailides, T.J., Crisosto, C.H, Dlott, J.W., Ramirez, H.T., Yokata, G.T. and Morgan, D.P. 1995. Excess nitrogen raises nectarine susceptibility to disease and insects. California Agriculture, 49: 13-17.

Dhillon, W.S., Bindra, A.S. and Cheema, S.S. 1990. Comparative efficacy of single and split applied nitrogen on yield and quality of Perlette grapes. Paper presented at International Seminar on New Frontiers in Hort., held at Bangalore on 25-28 Nov.

Dhillon, W.S., Bindra, A.S., Cheema, S.S. and Singh, S. 1992. Effect of graded doses of nitrogen on vine growth, fruit yield and quality of Perlette grapes. Acta Hort., 321: 667-671.

Dhillon, W.S., Gill, P.P.S. and Singh, N.P. 2011. Effect of nitrogen, phosphorus and potassium fertilization on growth, yield and quality of pomegranate 'Kandhari'. Acta Hort., 890: 327-332.

Domingo, X., Villar, J.M., Arbones, A., Rufat, L. and Pascual, M. 2012. Water and nitrogen interaction in peaches for processing: 2007 vs. 2008. Acta Hort., 962: 341- 347.

Dumas, Y., Dadomo, M., Di- Lucca, G. and Grolier, P. 2003. Effects of environmental factors and agricultural techniques on antioxidant content of tomatoes. J. Sci. Food Agric., 83(5): 369-382.

Falguera, V, Lordan, J, Gatius, F, Pascual, M, Villar, J.M., Ibarz, A, and Rufat, J. 2012. Influence of nitrogen fertilization on polyphenol oxidase activity in peach fruits. Scientia Horticulturae. 142: 155157.

Fallahi, E., Righetti, T.L. and Proebsting, E.L. 1993. Pruning and nitrogen effects on elemental partitioning and fruit maturity in Bing sweet cherry. J. Plant Nutrition, 16 (5): 753-763.

Ferretti, G., Bacchetti, T., Belleggia, A. and Neri, D. 2010. Cherry antioxidants: from farms to table. Molecules., 15 (10): 6993-
7005.

Ferretti, G., Neri, D. and Bacchetti, T. 2014. Effect of Italian sour cherry (Prunus cerasus) on the formation of advanced glycation and products and lipid peroxidation. Food Nutr. Sci., 05 (16): 1568- 1576.

Garhwal, P.C., Yadav, P.K., Sharma, B.D., Singh, R.S. and Ramniw, A.S. 2014. Effect of organic manure and nitrogen on growth, yield and quality of kinnow mandarin in sandy soils of hot arid region. African Journal of Agricultural Research, 9 (34): 2638- 2647.

Gill, S.K. and Gill, P.P.S. 2016. Effects of different rates of nitrogen and potassium fertilizers on growth characters and leaf nutrient status of pear (Pyrus pyrifolia) cv. Patharnakh. Prog. Hort., 48 (2): 162166.

Hakkinen, S.H. and Torronen, A.R. 2000. Content of flavonols and selected phenolic acids in strawberries and Vaccinium species: Influence of cultivar, cultivation site and technique. Food Res. Int., 33 (6): 517- 524.

Hassan, A.H. 1990. Effect of nutrition and severity of pruning in peaches. Acta Hort., 274: 187-193.

Hernandez- Fuentes, A.D., Colinas, M.T.L., Cortes, J.F., Saucedo, C.V., Sanchez, P.G. and Alcazar, J.R. 2002. Effect of fertilization and storage conditions on postharvest quality of Zacatecas-Type peach (Prunus persica (L.) Batsch). Acta Hort., 594: 507- 515.

Hobson, G.E. 1963. Influence of nitrogen and potassium fertilizers on pectic enzyme activity in tomato fruits. Journal of the Science of Food and Agriculture, 14 (8): 550-554.

Jia, H.J., Mizuguchi, K., Hirango, K. and Okamoto, G. 2006. Effect of fertilizer application level on pectin composition of Hakuho peach (Prunus persica Batsch) during maturation. HortScience. 41 (7): 1571- 1575 .

Jin, P., Wang, S.Y., wang, C.Y. and Zheng, Y. 2011. Effect of cultural system and 
storage temperature on antioxidant capacity and phenolic compounds in strawberries. Food Chem., 124 (1) 262270.

Jordan, M.O., Wendler, R. and Millard, P. 2009. The effect of autumn $\mathrm{N}$ supply on the architecture of young peach (Prunus persica L.) trees. Trees, 23: 235-245.

Kalt, W. 2005. Effects of production and processing factors on major fruit and vegetable antioxidants. J. Food. Sci., 70 (1): 1365- 2621.

Kanwar, J.S. and Nijjar, G.S. 1983. Effect of different pruning and fertilizer treatments on growth, yield and quality of peach [Prunus persica (L). Batsch] cv. Flordasun. Indian J. Hort., 40: 48- 54.

Klein, I., Levin, I., Bar- Yoseph, B., Assaf, R. and Berkovitz, A. 1989. Drip nitrogen fertigation of Starking Delicious apple trees. Plant Soil, 119: 305-314.

Kumar, S.P. and Dhander, D.G. 1996. Response of pomegranate to NPK fertilization. Indian J. Hort., 53: 114-117.

Lombardi- Boccia,G., Lucarini, M.Lanzi, S., Aguzzi, A. and Cappelloni, M. 2004. Nutrients and antioxidant molecules in yellow plums (Prunus domestica L.) from conventional and organic production: a comparative study. J. Agric Food Chem., 52 (1): 90-94.

Maggio, A., De Pascale, S., Paradiso, R. and Barbieri, G. 2013. Quality and nutritional value of vegetables from organic and conventional farming. Scientia Horticulturae, 164: 532- 533.

Marcelle, R.D. 1995. Mineral nutrition and fruit quality. Acta Hort., 383: 219-226.

Mido, H. and Ishikawa, K. 2016. Effective one split application of controlled release fertilizer for Citrus unshiu Marc 'Miyagawa Wase'. Horticultural Research: Japan, 15 (2): 145- 152.

Moreau- Rio, M.A., Scandella, D. and Venien, S. 1995. Peches et nectarines: image et perception de la qualite, analyse sensorielle. Infos- Ctifl, 108: 12-17

Ochoa- Velasco, C.E., Valadez- Blanco, R., Salas- Coronado, R., Sustaita- Rivera, F.,
Hernandez- Carlos, B., Garcia- Ortega, S. and Santos- Sanchez, N. F. 2016. Effect of nitrogen fertilization and Bacillus licheniformis biofertilizer addition on the antioxidants compounds and antioxidant activity of greenhouse cultivated tomato fruits (Solanum lycopersicum L. var. Sheva). Scientia Horticulturae, 201: 338345.

Olmstead, M., Zotarelli, L., Brecht, J. and Ross, M. 2015. Impact of nitrogen on vegetative growth of mature peach trees in a subtropical climate. Acta Hort., 1084: 459- 464.

Pande, K.K. and Dimri, D.C. 2018. Effect of different nitrogen levels through neem coated urea and calcium sprays on growth and yield of peach cv. Red June. Journal of Hill Agriculture 9(2): 137-143

Pande, K.K. and Dimri, D.C. 2018. Study on different nitrogen regimes through neem coated urea and calcium sprays on physicochemical attributes and maturity of peach fruits. Journal of Pharmacognosy and Phytochemistry, 18; 7(2): 1747-1753

Pande, K.K., Dimri, D.C. and Kumar, S. 2018. Effect of different nitrogen levels through neem coated urea and calcium sprays on leaf and soil NPK and Ca status and phytotoxicity in peach. International Journal of Agricultural Sciences, 14 (2): 381-388

Pande, K.K., Dimri, D.C., Roa, V.K., Shant Lal, Uniyal, S.P. and Pal, R.S. 2017. Response of different nitrogen regimes through neem coated urea and calcium sprays on bio-chemical attributes and antioxidant activities of peach. International Journal of Chemical Studies, 5(6): 1528-1534

Pangborn, R.M. 1963. Relative taste intensities of selected sugars and organic acids. Journal of Food Science, 28: 726-733.

Poorter, H. and Nagel, O. 2000. The role of biomass allocation in the growth response of plants to different levels of light, $\mathrm{CO}_{2}$, nutrients and water: a quantitative review. Aust. J. Plant Physiol., 27: 595- 607.

Radivojevic, D., Zivic, M., Milivojevic, J., 
Oparnica, C. and Velickovic, M. 2016. Effect of 6-BA+ $\mathrm{GA}_{4+7}$ and nitrogen fertigation on feathering of Golden Reinders apple nine- month- old nursery trees. Acta Hort., 1139: 497- 501.

Rai, M., Dey, P., Gangopadhyay, K.K., das, B., Nath, V., Reddy, N.N. and Singh, H.P. 2002. Influence of nitrogen, phosphorus and potassium on growth parameters, leaf nutrient composition and yield of litchi (Litchi chinensis). Indian J. Agric. Sci., 72 (5): 267- 270.

Rakiceevic, M., Ogasanovic, D., Mitrovic, M., Blagojevic, M. and Stajic, Z.K. 2007. The effects of plant density and rate of fertilizers on yield and fruit size of plam cultivar Cacanska Lepotica. Acta Hort., 734: 401- 405.

Ram, R.A., Rajput, M.S. and Raghuvanshi, S.R. 1999. Effect of controlled release fertilizers on growth, yield and fruit quality of guava cv. Sardar Ustochrepts. Indian J. Hort., 56 (2): 104-111.

Ro, H.M. and Park, J.M. 2000. Nitrogen requirement and vegetative growth of potlysimeter- grown Fuji apple trees fertilized by drip irrigation with three nitrogen rates. J. Hortic. Sci. Biotechnol., 75: 237- 242.

Rufat, J., Arbonés, A., Villar, P., Domingo, X., Pascual, M. and Villar, J.M. 2010. Effects of irrigation and nitrogen fertilization on growth, yield and fruit quality parameters of peaches for processing. Acta Hort., 868: 87-93.

Saenz, J.L., DeJong, T.M. and Weinbaum, S.A. 1997. Nitrogen stimulated increase in peach yields are associated with extended fruit development period and increased fruit sink capacity. J. Amer. Soc. Hort. Sci., 122 (6): 772-777.

Saha, S., Singh, Y.V., Gaind, S. and Kumar, D. 2015. Water productivity and nutrient status of rice soil in response to cultivation techniques and nitrogen fertilization. Paddy Water Environ., 13: 443- 453.

Saini, P., Pandey, A. and Rehalia, A.S. 2013. Effect of nitrogen fertilizer on fruit yield and quality of plum (Prunus salicina L.).

Current Advances in Agricultural Sciences, 5 (1): 132-134.

Sharma, D.P. and Chauhan, J.S. 2004. Response of pruning intensities and fertilizer treatments on yield, fruit quality and photosynthetic efficiency of peach. Acta Hort., 662: 237- 241.

Sharma, R.R. 2006. Fruit Production: Problems and Solutions. International Book Distribution Co., Lucknow.

Shifferstein, H.N.J. and Fritjers, J.E.R. 1990. Sensory integration in citric acid/ sucrose mixtures, Chemical Senses, 15 (1): 87109

Silva, D.J., Bassoi, L.H., Rocha, M.G., Silva, O., Deon, M.D. 2016. Organic and nitrogen fertilization of soil under 'syrah' grapevine: effects on soil chemical properties and nitrate concentration. Rev Bras Cienc Solo, 40.

Singh, D. and Chauhan, J.S. 2002. Studies on pruning and nitrogen fertilization in peach. Indian J. Agric. Res., 36 (2): 128132.

Singh, D. and Singh, R. 2002. Nitrogen nutrition of peach: A review. Agricultural Reviews, 23 (1): 46-52

Singh, D., Chauhan, J.S. and Kaith, N.S. 1995. Effect of pruning and nitrogen on leaf nutrient status of peach (Prunus persica). Indian J. Agri Sci., 65 (5): 337-340.

Singh, S.R., Sharma, A.K. and Sharma, M.K. 2009. Influence of NPK combinations at different altitudes and aspects on fruit yield, quality and leaf nutrient status of apple cv. Red Deliciuos. Indian J. Hort., 66 (2): 175- 182.

Souza, F., Argenta, L.C., Nava, G., Ernani, P.R. and Amarante, C.V.T. 2013. Quality of Fuji apples affected by nitrogen and potassium fertilization in two soil types. Brazilian Magazine of Fruit Culture, 35 (1): 305-315.

Squires, E. 2013. The impact of different nitrogen fertilizer rates on soil characteristics, plant properties and economic returns in a southeastern Minnesota cornfield. St. Olaf College, 
Minnesota.

Tahir, I.I., Johansson, E. and Olsson, M.E. 2007. Improvement of quality and storability of apple cv. Aroma by adjustment of some pre- harvest conditions. Scientia Horticulturae, 112: 164- 171

Tarozzi, A., Hrelia, S., Angeloni, C., Morroni, F., Biagi, P., Guardigli, M., CantelliForti, G. and Hrelia, P. 2006. Antioxidant effectiveness of organically and nonorganically grown red oranges in cell culture system. Eur. J. Nutr., 45 (3): 152158.

Taylor, B.K. and May, L.H. 1967. The nitrogen nutrition of the peach tree. II. Storage and mobilization of nitrogen in young trees. Aust. J. Biol. Sci., 20: 389- 411.

Toselli, M, Baldi, B., Marangoni,, M., Noferini, G., Bregoli, A.M. and Ndagijimana, M. 2010. Effect of mineral and organic fertilization and ripening stage on the emission of volatile organic compounds and antioxidant activity of Stark Red Gold nectarine. Acta Hort., 868: 381387.

Unuk, T., Tojnko, S., Cmelik, Z. and Stopar, M. 2006. Polyphenol content in apple fruits as affected by crop load and rate of applied nitrogen. Acta Hort., 721: 173176.

Valavanidis, A., Vlachogianni, T., Psomas, A.
Zovoili, A. and Siatis, V. 2009. Polyphenolic profile and antioxidant activity of five apple cultivars grown under organic and conventional agricultural practices. Int. J. Food Sci. Technol., 44 (6): 1167-1175.

Wang, S.Y., Chen, C.T., Sciarappa, W., Wang, C.Y. and Camp, M.J. 2008. Fruit quality, antioxidant capacity and flavonoid content of organically and conventionally grown blueberries. J. Agric. Food Chem., 56 (14): 5788- 5794.

Wargo, J.M., Merwin, I.A. and Watkins, C.B. 2003. Fruit size, yield and market value of Gold Rush apple are affected by amount, timing and method of nitrogen fertilization. HortTechnology, 13 (1): 153- 161.

Weinbaum, S.A., Johnson, R.S. and Dejong, T.M. 1992. Causes and consequences of over fertilization in orchards. HortTechnology, 2: 112-121.

Wrona, D. 2006. Response of young apple trees to nitrogen fertilization, on two different soils. Acta Hort., 721: 153- 158.

Yuri, J.A., Maldonado, F.J., Razmilic, I., Neira, A., Quilodran, A. and Palomo, I. 2012. Concentrations of total phenols and antioxidant activity in apple do not differ between conventional and organic orchard management. J. Food Agric. Environ., 10: 207-216.

\section{How to cite this article:}

Kamal Kumar Pande and Dinesh Chandra Dimri. 2020. Response of Nitrogen Application in Fruit Trees: A Review. Int.J.Curr.Microbiol.App.Sci. 9(05): 545-559.

doi: https://doi.org/10.20546/ijcmas.2020.905.062 